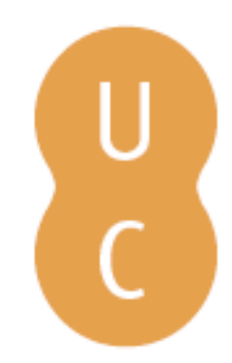

\title{
pommalina
}

\section{"As dinâmicas europeias, entre os Estados, as redes e os atores multiterritoriais": uma visão desde os Estudos Europeus}

\author{
Autor(es): $\quad$ Sebastião, Dina \\ Publicado por: Imprensa da Universidade de Coimbra \\ URL \\ persistente: URI:http://hdl.handle.net/10316.2/47308 \\ DOI: $\quad$ DOI:https://doi.org/10.14195/978-989-26-1849-4_17 \\ Accessed : $\quad$ 26-Apr-2023 15:57:11
}

A navegação consulta e descarregamento dos títulos inseridos nas Bibliotecas Digitais UC Digitalis, UC Pombalina e UC Impactum, pressupõem a aceitação plena e sem reservas dos Termos e Condições de Uso destas Bibliotecas Digitais, disponíveis em https://digitalis.uc.pt/pt-pt/termos.

Conforme exposto nos referidos Termos e Condições de Uso, o descarregamento de títulos de acesso restrito requer uma licença válida de autorização devendo o utilizador aceder ao(s) documento(s) a partir de um endereço de IP da instituição detentora da supramencionada licença.

Ao utilizador é apenas permitido o descarregamento para uso pessoal, pelo que o emprego do(s) título(s) descarregado(s) para outro fim, designadamente comercial, carece de autorização do respetivo autor ou editor da obra.

Na medida em que todas as obras da UC Digitalis se encontram protegidas pelo Código do Direito de Autor e Direitos Conexos e demais legislação aplicável, toda a cópia, parcial ou total, deste documento, nos casos em que é legalmente admitida, deverá conter ou fazer-se acompanhar por este aviso.

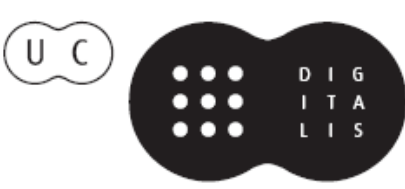


Euro-Atlântico:

Espaço de Diálogos

Isabel Maria Freitas Valente

Iranilson Buriti de Oliveira

(Coord)

\section{VISÕES \\ INTERDISCIPLINARES \\ DA EUROPA \\ E DO MUNDO:}

uma experiência de convergência

disciplinar em homenagem a

Maria Manuela Tavares Ribeiro

Alexandra Aragão

Isabel Maria Freitas Valente

Dulce Lopes

(org.)

Editora da Universidade Federal de Campina Grande

Imprensa da Universidade de Coimbra

2019 


\title{
“AS DINÂMICAS EUROPEIAS, ENTRE OS ESTADOS, AS REDES E OS ATORES MULTITERRITORIAIS", UMA VISÃO DESDE OS ESTUDOS EUROPEUS
}

\author{
Dina Sebastião
}

Da interessante reflexão sobre os fenómenos de multiterritorialização de diversos tipos de atores, e dos seus poderes derivados e agregados dessa sobreposição, permeabilização e complementaridade de espaços, mas também do seu contraste, i. e., dos que continuam presos a um espaço sem capacidade de usufruir de uma dimensão transnacional do mundo, suscita-me acrescentar a esta interessante abordagem geográfica a perspetiva da ciência política (encarada aqui enquanto área científica nuclear dos Estudos Europeus e, portanto, enquadrandose numa abordagem de estudo aos fenómenos políticos da UE), aliás, como o autor acaba por fazer a ligação na parte final do seu texto, mas que também está inerente na natureza subdisciplinar geopolítica do mesmo. Assim, deixamos as seguintes sugestões de investigação que se poderiam relacionar:

- Estudo sobre a influência dos mecanismos de governação multiníveis da União Europeia na criação de comunidades e de uma cidadania regional transfronteiriças. A existência de instrumentos legais supranacionais no âmbito da Política Regional da UE (que possibilitam a criação de organismos de governação administrativa regional transfronteiriça, com o objetivo de racionalizarem a gestão político-administrativa do desenvolvimento do território entre regiões de fronteira), com o desenvolvimento das suas atividades e políticas em benefício dos seus habitantes, beneficiarão as suas vivências multiterritoriais. A evidenciarem-se, estes resultados poderão ter impacto ao nível da construção identitária e de participação política nas designadas eurorregiões, o que poderá ainda ter repercussão em termos de reclamação de poder político no sistema institucional da UE.

- A referência à movimentação de atores "com um peso elevado na geografia do poder", organizados em redes, como "entidades bancárias 
e financeiras, bolsas de valores e companhias de seguro; empresas multinacionais" convoca-nos para o estudo da capacidade de influência do poder corporativo destes setores no poder político e para a aferição da possível erosão de equilíbrios clássicos da democracia. Com uma presença multinacional em setores com um impacto determinante para a estabilidade económico-social, estes atores têm um poder tácito de persuasão e coação sobre a decisão política. Esta, por sua vez, apesar de continuar a reger-se por processos formais democráticos (eleições, debates parlamentares, oposição) é altamente condicionada pela potencialidade do poder económico internacionalizado. Face a este, os formais processos democráticos, as eleições, a oposição, os debates parlamentares ou a atuação sindical continuam a existir, e os processos eleitorais até levam novos políticos ao poder, mas as políticas pouco mudam, o que sustenta o conceito de pós-democracia de Colin Crouch ${ }^{1}$. Como exemplo, temos a crise das dívidas soberanas na Zona Euro, que veio acrescentar argumentos ao já longo debate sobre o défice democrático na $\mathrm{UE}^{2}$.

- Sendo a multiterritorialidade vivenciada de forma diferente constituindo um "capital desigualmente distribuído", entre "uma elite que efetivamente usufrui da multiterritorialidade e da multi-escalaridade planetária, até aos grupos mais fixados à terra, como os indígenas e os pequenos agricultores, e aqueles quase totalmente dela excluídos", pode entrar aqui o campo das Relações Internacionais a par com o da Ciência Política. É pertinente investigar como as alterações climáticas e as perspetivas de esgotamento dos recursos da Terra convocam para a fragilidade das organizações internacionais num compromisso global para o combate a esses problemas. Mas face ao balanço entre países poluidores e países sofredores com a degradação ambiental ${ }^{3}$, urge também problematizar a legitimidade da soberania nacional para as

\footnotetext{
${ }^{1}$ Crouch, C. (2004). Post-Democracy. Cambridge: Polity Press.

${ }^{2}$ Schmidt, V. A. (2007). L’Union Européenne crée-t-elle ou détruit-elle la démocratie? Politique Étrangère. $\mathrm{N}^{\circ} 3$, p. 517-528.

3 Hoffmand, Matthew J. (2014). Climate Change. In Weiss, T.., Wilkinson, R. (eds), International Organizations and Global Governance (605-616). London and NY: Routledge.
} 
decisões de combate a estes problemas.

- No domínio dos movimentos migratórios, e no que reporta à Europa enquanto lugar de origem e destino de múltiplas diásporas, realça-se o estudo sobre o impacto das migrações no discurso político e na construção da identidade europeia. Sugerimos a pertinência de investigar a forma como os movimentos migratórios se repercutem numa clivagem económica norte-sul (quer ao nível intra-Europa, quer global), traduzida nos discursos partidários, importando aqui identificar como variável países com saldos migratórios positivos e negativos ${ }^{4}$. Realça-se, ainda, a importância de estudar as questões da representação identitária assentes na dicotomia nós versus os outros como elemento de competição política e argumento nuclear do discurso e da competição partidária de novos partidos extremistas e nacionalistas.

Enfim, consideramos que a abordagem da ciência política agrega uma perspetiva de estudo complementar sobre as relações de poder nos clássicos sistemas políticos e nos sistemas em construção, como a União Europeia, problematizando a sua atuação, pertinência e articulação no âmbito das dinâmicas políticas que a globalização impõe.

${ }^{4}$ Kriesi, H. (2016). The Politicization of European integration. Journal of Common Market Studies, 54, p. 32-47. 